\title{
Administration of Three Autochthonous Bacillus subtilis Strains Induce Early Appearance of Gastric Glands and Vestiges of Pylorus in Piaractus mesopotamicus Larvae
}

Marcos Gabriel Guidoli'1-3, David Roque Hernández ${ }^{1}$, Silvia Irene Boehringer ${ }^{2}$, Sebastián Sánchez ${ }^{1}$ and María Elena Fátima Nader-Macías ${ }^{3}$ ${ }^{1}$ Instituto de Ictiología del Nordeste (INICNE), Argentina

${ }^{2}$ Cátedra de Microbiología-Facultad de Ciencias Veterinarias-Universidad Nacional del Nordeste. CP: 3400, Sargento Cabral 2139, Corrientes Capital, Corrientes, Argentina ${ }^{3}$ Centro de Referencia de Lactobacilos (CERELA-CONICET). CP: T4000ILC, Chacabuco 145, San Miguel de Tucumán, Tucumán, Argentina

\begin{abstract}
Autochthonous microorganisms as probiotics are a novel alternative to antibiotics. The genus Bacillus is highly used by its ability to survive on adverse conditions. Piaractus mesopotamicus, a native fish, is the most produced specie in Argentinian aquaculture. The low level of knowledge, high stress conditions and demand of animals led to a deficit in the number of larvae and fry. The aim of this study was to evaluate the probiotic effect of previously selected autochthonous Bacillus on biometrical parameters of $P$. mesopotamicus larvae when administered together in a combined suspension in different doses and stages. Results showed that the bacterial administration did not cause significant effects on the variables evaluated. However, the dose containing $6 \times 107 \mathrm{CFU}$ L-1 of each strain showed the highest average values of P. mesopotamicus biological parameters, regardless the stage of administration. Histological evaluations of animals administered with this dose did not showed adverse effects and indicated the capability of this dose, administered in a particularly period of time, to stimulate the early appearance of gastric glands, vestiges of what would be the pylorus and a higher development of liver. Thus, we proposed the safe use of this dose in a combined probiotic mixture to be studied in further assays.
\end{abstract}

Keywords: Bacillus subtilis; Piaractus mesopotamicus; Probiotics; Aquaculture; Larvae; Beneficial effects

\section{Introduction}

The use of native species in aquaculture of Northeastern Argentina allowed their predominance in the National fish production chart. Piaractus mesopotamicus is the most cultivated fish in the country since 2012 , representing a $52.22 \%$ of the total production. Indigenous fishes had the advantage of resist to native environmental conditions. The demand of animals for breeding and fattening, the stress conditions in intensive culture systems and the low survival indexes of larvae and fry led to a deficit in the number of animals available. These facts brought the need of novel techniques to increase the production parameters. Antibiotics emerged as a solution, frequently applied as growing factors, anti-infectious agents and tranquilizers [1,2]. However, the European Food Safety Authority (EFSA) proposed the prohibition on their use as additives in foods [3] supported by the resistance transference [4], the toxicity of antibiotic residues [5], the appearance of allergies [6], the unbalance of intestinal microbiota [2] and environmental risks. Although expected, these regulations urged the search of more extensive production systems without the requirement of using additives, and/or the application of natural, novel and safe products.

Theuse of probioticsattemptsto replace the use of chemotherapeutics in animal production [6-8]. Probiotics for aquaculture were defined by Verschuere et al. [6] as "a live microbial adjunct which has a beneficial effect on the host by modifying the host associated or ambient microbial community, by ensuring improved use of feed or enhancing its nutritional value, by enhancing the host response toward disease or by improving the quality of its ambient environment". They were applied in a variety of terrestrial and aquatic hosts (www.isapp.org) with a wide range of beneficial effects: inhibitory activity against pathogens, nonspecific immune response stimulation, immunomodulatory effect, decrease of mortality and increase of growth rate and production [921]. Commercial probiotics are relatively ineffective in fishes, mainly because most of them include non-aquatic strains unable to survive and remain viable in the intestinal environment of fishes [22]. Then, it is essential to study cultivable autochthonous microorganisms as putative probiotics since they are more likely to survive and remain in the fish gastrointestinal tract [23].

Bacillus spp. has been used for several years in fermentation products or as spore-based supplements [24]. Recently they were proposed as gut commensals rather than solely soil micro-organisms [25-28]. Over other non-spore formers microorganisms, Bacillus have the advantage of being stable and resistant to the gastric barrier and storage conditions $[24,29]$.

In previous in vitro studies our group selected three autochthonous B. subtilis strains as novel putative beneficial microorganisms [30]. However, the definitive manners and beneficial effects of potentially probiotic strains should be evaluated through animal models (www. isapp.org) [31]. The in vivo assays for the study of probiotics for aquaculture have three critical items: the stage of biological cycle, the optimal dose and the way in which microorganisms should be administered to the host. Pasteris et al. [32] suggested that the colonization of the skin (or scams) and the gastrointestinal tract occurs together with the ontogeny and afterwards, the ingestion of

*Corresponding author: María EF Nader-Macías, Centro de Referencia para Lactobacilos (CERELA-CONICET), Chacabuco 145, CP: T4000ILC, San Miguel de Tucumán, Argentina, Tel: +54-381-431-0465; Fax: +54-381-400-5600; E-mail: fnader@cerela.org.ar

Received February 26, 2016; Accepted March 18, 2016; Published March 22 2016

Citation: Guidoli MG, Hernandez DR, Boheringer SI, Sanchez S, NaderMacias MEF (2016) Administration of Three Autochthonous Bacillus subtilis Strains Induce Early Appearance of Gastric Glands and Vestiges of Pylorus in Piaractus mesopotamicus Larvae. J Bioprocess Biotech 6: 271. doi:10.4172/21559821.1000271

Copyright: () 2016 Gabriel GM, et al. This is an open-access article distributed under the terms of the Creative Commons Attribution License, which permits unrestricted use, distribution, and reproduction in any medium, provided the original author and source are credited. 
Citation: Guidoli MG, Hernandez DR, Boheringer SI, Sanchez S, Nader-Macias MEF (2016) Administration of Three Autochthonous Bacillus subtilis Strains Induce Early Appearance of Gastric Glands and Vestiges of Pylorus in Piaractus mesopotamicus Larvae. J Bioprocess Biotech 6: 271. doi:10.4172/2155-9821.1000271

Page 2 of 5

microorganisms in larval stages could result in the establishment of a dominant intestinal microbiota that persist during the first stages of the biological cycle. Unfortunately, there is no general consensus on the other two critical terms. Bibliographic references suggest doses of administration ranging from $1 \times 10^{3}$ to $1 \times 10^{9} \mathrm{CFU}$. The last critical item is the way of administration, being widely used the balanced feed or the live aliment as a way to deliver microorganisms $[16,33,34]$. Therefore, the aim of this work was to evaluate the effect of the administration of the suspension containing these three autochthonous strains on the survival, mean weight, biomass and histological parameters of $P$. mesopotamicus larvae.

\section{Material and Methods}

\section{Bacillus strains}

Autochthonous B. subtilis strains A252, A253 and A254 were isolated from gills and medium intestine sections of $P$. mesopotamicus specimens. They were selected as potentially beneficial microorganisms based on the ability to express beneficial properties in "in vitro" tests. They were probed to resist the conditions of the gastrointestinal tract of fishes and to therapies used in aquaculture facilities. They were included in the Laboratorio de Sanidad Animal of the Estación Experimental Agropecuaria Rafaela belonging to the Instituto Nacional de Tecnología Agropecuaria (INTA) under Budapest treaty [35] for patent aims [30].

\section{Bacteria culture}

The spore forming bacteria described in the above section were grown daily in $400 \mathrm{~mL}$ nutrient broth $\left(\right.$ Britannia $^{\odot}$ ) and incubated at $37^{\circ} \mathrm{C}$ under constant shaking conditions for $8 \mathrm{~h}$. Bacterial cells were harvested by centrifugation at $3000 \mathrm{~g}$ for $10 \mathrm{~min}$ at $4^{\circ} \mathrm{C}$, washed twice with sterile distilled water and suspended to obtain the adequate numbers.

\section{Live food preparation}

$1 \mathrm{~L}$ suspension of freshwater containing $1 \mathrm{~g}$ of brine shrimp cysts Artemia sp., $15 \mathrm{~g}$ of $\mathrm{NaCl}$ and $2 \mathrm{~g}$ of sodium bicarbonate was submitted to incubation process under intense aeration and lightening for $24 \mathrm{~h}$. Live hatched nauplii were filtered, suspended in freshwater and counted in order to obtain an approximate concentration of the solution [36].

\section{Fish reproduction}

Pacu larvae were obtained by controlled reproduction from $P$. mesopotamicus's broodstock. Spawning was induced by injection of pituitary extract of Prochilodus lineatus according to Da Silva et al. [37]. The sexual gametes were obtained by the stripping technique, mixed immediately in a bowl, and suspended at the required concentration [38]. Aliquots of $1 \mathrm{~mL}$ were counted in order to obtain an approximate concentration of fecundated eggs.

\section{Experimental design and sampling}

Experimental units were settled as $5 \mathrm{~L}$ plastic fishbowls with a constant recirculation system and approximately 300 fecundated eggs. The three Bacillus subtilis strains were administered, in a combined suspension (BAC), in three different concentrations: $4\left(6 \times 10^{4} \mathrm{CFU}\right.$ $\left.\mathrm{L}^{-1}\right), 7\left(6 \times 10^{7} \mathrm{CFU} \mathrm{L}^{-1}\right)$ and $10\left(6 \times 10^{10} \mathrm{CFU} \mathrm{L}^{-1}\right)$ of each strain and at different stages of the biological cycle of larvae: $\mathrm{E}$ (from the time of fecundation of the eggs until the beginning of the exogenous feeding- 5 days), $\mathrm{L}$ (from the beginning of the exogenous feeding until the end of the assay in laboratory-from day 5 up to day 15) and E\&L (from the fecundation of the eggs until the end of the assay in laboratory- from day 0 up to day 15). Control units (CTRL) were assayed with no addition of bacteria.

During stage E the bacterial suspension was added directly to the fish bowls four times a day with previous stop of water recirculation which was restarted one hour after. In L experimental units, bacteria were co-incubated with live food during two hours previous to administration; this procedure was performed ad libitum four times a day. Water recirculation was interrupted before alimentation and restored one hour after. Water quality determinations of $\mathrm{pH}$, dissolved oxygen and temperature were performed daily in each experimental unit.

\section{Sampling}

At day 15, larvae were counted and weighed to obtain values of survival, mean weight and biomass. To evaluate the normal development, macroscopic evaluations were performed with binocular magnifier Optical Kyowa model SDZ. For histological studies, 10 larvae per treatment were collected and anaesthetized by chilling on ice, fixed in Bouin's solution (saturated picric acid $3000 \mathrm{ml}$, formaldehyde 1000 $\mathrm{ml}$, glacial acetic acid $200 \mathrm{ml}$ ) for $12 \mathrm{~h}$, washed twice with alcohol $70^{\circ}$ and maintained in this solution until processing. Samples were then routinely processed for histology, stained with haematoxylin and eosin and analyzed by light microscopy using a Leica DM500 microscope, a Leica ICC50 digital camera and the Leica Application Suite 3.4.1 image analysis system [39].

The procedures and experimental protocols applied to the animals in this work were in accordance with the ethical principles of animal experimentation, and approved according to protocol n. 0019/14-201102204 and 14-2012-03865 by the Ethics and Biosafety Committee of the School of Veterinary Sciences of the Northeast National University (UNNE) of Argentine.

\section{Statistical evaluation}

All the assays were performed by triplicate using a completely randomized design. Each replicate corresponds to different parents, excluding the genetic factor of the experiment. Statistical analyses were carried out using Statistica 6.0 for Microsoft Windows. Comparisons were performed, first, by a one way ANOVA including the ten experimental groups followed by a control vs. treatments comparison. Later, results were compared, excluding the control, by using a factorial two-way ANOVA with subsequent post hoc test in order to evaluate the main effects of doses and stages as well as the interactions between them. When interaction and significant effects were not detected, results were evaluated by orthogonal polynomials for trend analysis.

\section{Results and Discussion}

The values of survival, mean weight and produced biomass obtained after the administration of the microbial mixture BAC to eggs and/or larvae of Piaractus mesopotamicus analyzed through one way ANOVA, did not indicate significant differences between treatments and control group ( $\mathrm{p}>0.05$ ) (Table 1 ). The two ways ANOVA analysis did not show neither interaction between doses and stages nor significant effect of dose or stage over any of the variables analyzed ( $p>0.05)$ (Figure 1). Although statistical evaluations did not demonstrate significant differences, the average values of each biometrical parameter indicated that larvae administered with the BAC suspension containing 6 $\times 10^{7} \mathrm{CFU} \mathrm{L}^{-1}$ of each strain, regardless the stage of administration, showed the best outcome (Figure 2). These results indicate that there is not a remarkable effect of the probiotic on the evaluated variables. 
Citation: Guidoli MG, Hernandez DR, Boheringer SI, Sanchez S, Nader-Macias MEF (2016) Administration of Three Autochthonous Bacillus subtilis Strains Induce Early Appearance of Gastric Glands and Vestiges of Pylorus in Piaractus mesopotamicus Larvae. J Bioprocess Biotech 6: 271. doi:10.4172/2155-9821.1000271

Page 3 of 5

\begin{tabular}{|c|c|c|c|c|c|}
\hline Variable & N & SS & df & MS & P-value \\
\hline Mean weight (mg) & 30 & 8.14 & 9 & 0.90 & 0.4490 \\
\hline Survival (\%) & 30 & 552.03 & 9 & 61.34 & 0.85 \\
\hline Biomass (mg) & 30 & 30362.53 & 9 & 3093.73 & 0.5841 \\
\hline
\end{tabular}

$\mathrm{N}$ : Number of values; SS: Sum of squares due to the source; df: Degrees of freedom in the source; MS: Mean sum of squares due to the source; F: F-statistic

Table 1: One way ANOVA of mean weight, survival and biomass of $P$. mesopotamicus larvae administered with mixture BAC in different doses and stages.

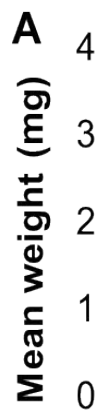

0

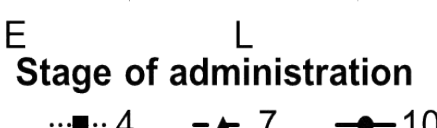

B

100

80

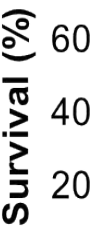

C

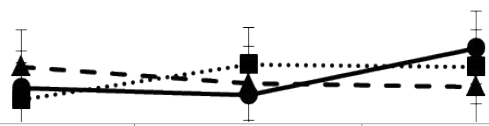

0

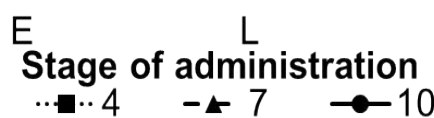

$E \& L$
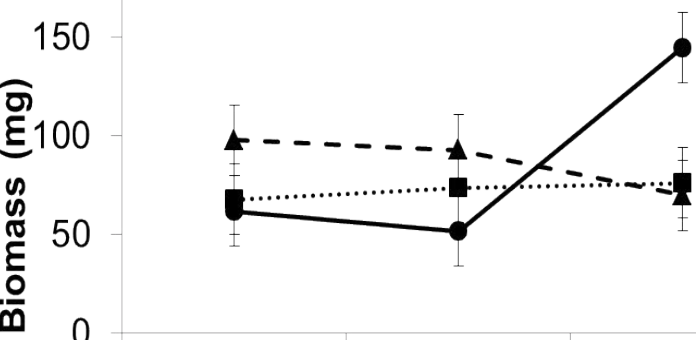

E Stage of administration

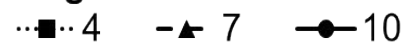

Figure 1: Dose-stage interactions over mean weight $(A)$, survival $(B)$ and biomass (C) of $P$. mesopotamicus larvae administered with BAC mixture in different doses: $4\left(6 \times 10^{4} \mathrm{CFU} \mathrm{L}^{-1}\right), 7\left(6 \times 10^{7} \mathrm{CFU} \mathrm{L}^{-1}\right)$ and $10\left(6 \times 10^{10} \mathrm{CFU}\right.$ $\mathrm{L}^{-1}$ ) and stages: $E$ (from the time of fecundation of the eggs until the beginning of the exogenous feeding - 5 days), $L$ (from the beginning of the exogenous feeding until the end of the assay in laboratory - from day 5 up to day 15) and E\&L (from the fecundation of the eggs until the end of the assay in laboratory from day 0 up to day 15). Vertical bars indicate standard error.

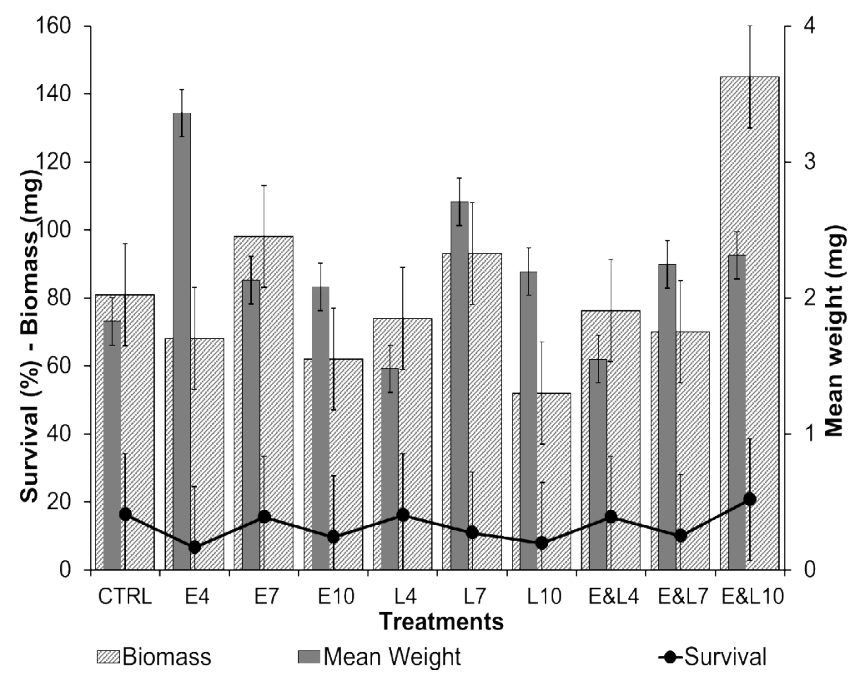

Figure 2: Mean weight, survival and biomass of Piaractus mesopotamicus after control (CTRL) and bacterial treatments on day 15 . Vertical bars indicate Standard Error of means (SE).

However, dose $7\left(6 \times 10^{7} \mathrm{CFU} \mathrm{L}^{-1}\right.$ of each strain) of the BAC suspension (composed by B. subtilis strains A252, A253 and A254), showed to be the most suitable concentration for its incorporation to a composite probiotic formula. This potentially probiotic mixture will be tested in vivo in future assays for $P$. mesopotamicus aquaculture. Thus, these strains were included in a type collection culture under Budapest treaty to initiate patent procedures [35]. The better effect of medium doses (quadratic effect) was described by several authors in aquaculture. Bagheri et al. [34] established that more probiotic cells in diets and host intestine does not necessarily result in a highest or improved growth, survival and protein efficiency ratio of animals, when administering two Bacillus strains in different concentrations to rainbow trout. Faramarzi et al. [40] obtained similar results when administering Lactobacillus acidophilus at different doses to rainbow trout, indicating better results on the survival percentage when administering an intermediate dose. Kapareiko et al. [41] obtained similar results over survival when different concentrations of Vibrio sp. was administered to oyster larvae challenged with pathogens.

With the aim of evaluate that the previously selected dose did not produce any adverse effect to the animals, they were observed macro and microscopically. Macroscopic observations did not show differences in behavior and/or observable malformations between treated and control group. The histological evaluations demonstrated no translocation or aggrupation of microorganisms in any of the treatments, basic characteristic of the strains to be considered for probiotic use [31]. Histological samples of animals administered with dose 7 in stages $\mathrm{E}$ (from the time of fecundation of the eggs until the beginning of the exogenous feeding) (Figure 3B) and E\&L (from the fecundation of the eggs until the end of the assay in laboratory) 
Citation: Guidoli MG, Hernandez DR, Boheringer SI, Sanchez S, Nader-Macias MEF (2016) Administration of Three Autochthonous Bacillus subtilis Strains Induce Early Appearance of Gastric Glands and Vestiges of Pylorus in Piaractus mesopotamicus Larvae. J Bioprocess Biotech 6 : 271. doi:10.4172/2155-9821.1000271

(Figure 3C) were consistent to those obtained in fishes of control group (Figure $3 \mathrm{~A}$ ) and those reported in literature as normal for this stage of the biological cycle [42]. On the other hand, when evaluating the histological parameters of animals administered with dose 7 in stage $\mathrm{L}$ (from the beginning of the exogenous feeding until the end of the assay in laboratory), the appearance of gastric glands was evidenced, together with a higher developed liver and vestiges of what would be the pylorus (Figures 4 and 5), histological characteristics of animals in a more advanced stage of their biological cycle, as described by several authors for this and other fresh water fish species [43-45]. There are no references indicating the early development of the gastrointestinal tract of fishes as those described in the present work. Instead, there are several studies based on the ability of probiotics to restore or prevent histological alterations caused by pathogens and only a few evaluate minor modifications of the normal histological structure of different organs. Standen et al. [46] published that tilapia administered with a multi-species commercial probiotic showed a significant increment in the absorptive surface of intestine. Merrifield et al. [47] proved the ability of Pediococcus acidilactici to increase significantly the length of microvilli of proximal intestine of rainbow trout and Rodríguez Estrada et al. [48] reported that the administration of Enterococcus faecalis reduces the number of lipid vacuoles of enterocytes, increasing their functionality.

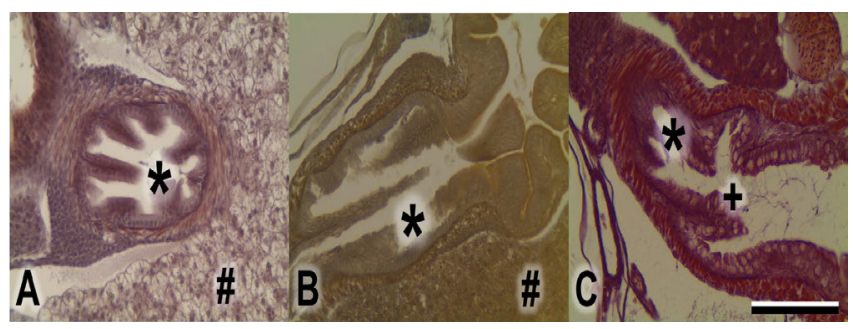

Figure 3: Structure of stomach $\left(^{*}\right)$, liver $(\#)$ and esophagus $(+)$ of contro group, without the addition of microorganisms, $(A)$ and larvae administered with suspension BAC in dose 7 and stages $E(B)$ and $E \& L(C)$. Bar indicates 100 $\mu \mathrm{m}$. Magnification $=40 \mathrm{X}$

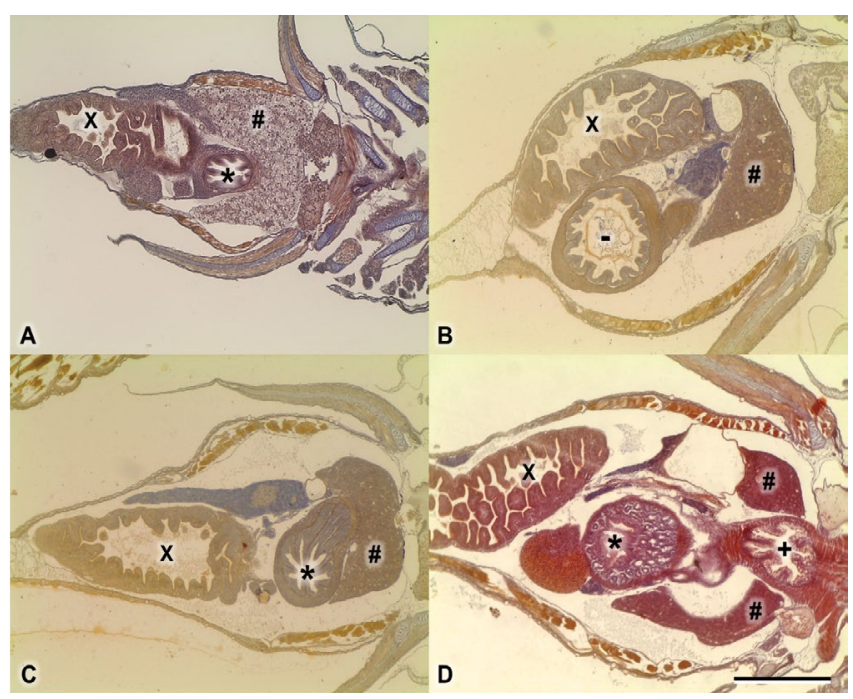

Figure 4: Structure of stomach $\left({ }^{*}\right)$, liver $(\#)$, intestine $(X)$, pylorus $(-)$ and esophagus $(+)$ of control group, without the addition of microorganisms, (A) and animals treated with BAC L7 (B, C y D). Bar indicates $300 \mu \mathrm{m}$. Magnification $=10 \mathrm{X}$.

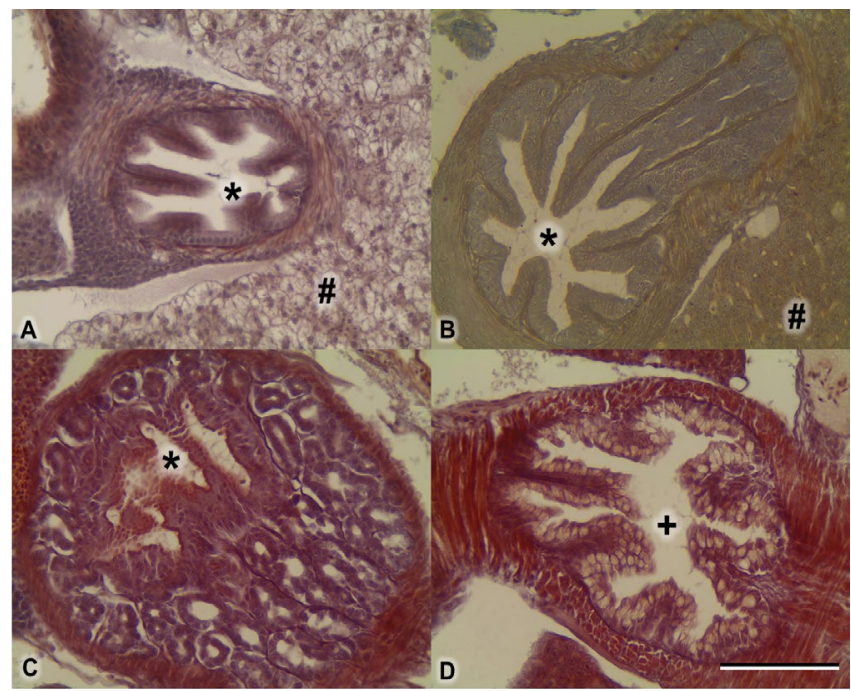

Figure 5: Structure of stomach $\left(^{*}\right)$ and esophagus $(+)$ of control group without the addition of microorganisms, (A) and animals administered with BAC suspension in dose 7 and stage $L$ (B, C y D). Bar indicates $100 \mu \mathrm{m}$. Magnification $=40 \mathrm{X}$.

\section{Conclusion}

The present work allows our research group to select the BAC suspension; containing $6 \times 10^{7} \mathrm{CFU} \mathrm{L}^{-1}$ of Bacillus strains A252, A253 and A254, to be assayed in further assays. In addition, it supports a new research area to evaluate the methods by which this bacterial suspension, administered to larvae from day 5 to 15 , induce an early development of the gastrointestinal tract.

\section{Acknowledgements}

The Argentinian National Council of Scientific and Technical Researches (Consejo Nacional de Investigaciones Científicas y Técnicas - CONICET), project PIP 744, together with the National Agency for Scientific and Technological Promotion (Agencia Nacional de Promoción Científica y Tecnológica- ANPCyT) through the Fund for Scientific and Technological Research (Fondo para la Investigación Científica y Tecnológica-FONCyT); projects PICTO-UNNE-2011-198, and PICT-1187; financed this study.

Some of the results of this paper were included in a patent presentation in Argentina (INPI Exp 20130103820).

\section{References}

1. Food and Drug Administration (1998) Aquaculture Drugs. In: Fish and Fishery Products Hazards and Control Guide, second ed., pp: 115-132. FDA Washington DC, USA.

2. Serrano PH (2005) Responsible use of antibiotics in aquaculture. Food and Agriculture Organization Fisheries Technical Paper: 469.

3. European Food Safety Authority (2008) Technical guidance: Update of the criteria used in the assessment of bacterial resistance to antibiotics of human or veterinary importance. The EFSA Journal 732: 1-15.

4. FAO/NACA/WHO Joint Study Group (1997) Food safety issues associated with products from aquaculture. WHO Technical Report Series 799. World Health Organization.

5. Statens Offentliga Utrednigar- National Public Investigations from Sweden (1997) Toxicological and related effects of antibacterial feed additives. Document $\mathrm{N}^{\circ}: 132$

6. Verschuere L, Rombaut G, Sorgeloos P, Verstraete W (2000) Probiotic bacteria as biological control agents in aquaculture. Microbiol Mol Biol Rev 64: 655-671.

7. Reid G, Sanders ME, Gaskins HR, Gibson GR, Mercenier A, et al. (2003) New scientific paradigms for probiotics and prebiotics. J Clin Gastroenterol 37: 105118. 
Citation: Guidoli MG, Hernandez DR, Boheringer SI, Sanchez S, Nader-Macias MEF (2016) Administration of Three Autochthonous Bacillus subtilis Strains Induce Early Appearance of Gastric Glands and Vestiges of Pylorus in Piaractus mesopotamicus Larvae. J Bioprocess Biotech 6: 271. doi:10.4172/2155-9821.1000271

8. Romalde JL, Ravelo C, López-Romalde S, Avendaño-Herrera R, Magariños B et al. (2005) Vaccination strategies to prevent emerging diseases for Spanish aquaculture. Dev Biol (Basel) 121: 85-95.

9. Gatesoupe FJ (1997) Siderophore production and probiotic effect of Vibrio sp. associated with turbot larvae, Scophthalmus maximus. Aquat Living Resour 10: $239-246$

10. Gildberg A, Mikkelsen H, Sandaker E, Ringø E (1997) Probiotic effect of lactic acid bacteria in the feed on growth and survival of fry of Atlantic cod (Gadus morhua). Hydrobiologia 352: 279-285.

11. Gibson LF, Woodworth J, George AM (1998) Probiotic activity of Aeromonas media on the Pacific oyster, Crassostrea gigas, when challenged with Vibrio tubiashii. Aquaculture 169: 111-120.

12. Gildberg A, Mikkelsen H (1998) Effects of supplementing the feed to Atlantic cod (Gadus morhua) fry with lactic acid bacteria and immuno-stimulating peptides during a challenge trial with Vibrio anguillarum. Aquaculture 167: 103-113.

13. Olsson JC, Jöborn A, Westerdahl A, Blomberg L, Kjelleberg S, et al. (1998) Survival, persistence and proliferation of Vibrio anguillarum in juvenile turbot, Scophthalmus maximus (L.), intestine and faeces. J Fish Dis 2: 1-9.

14. Queiroz J, Boyd CE (1998) Effects of a bacterial inoculum in channel catfish ponds. J World Aquac Soc 29: 67-73.

15. Ringø E, Vadstein O (1998) Colonization of Vibrio pelagius and Aeromonas caviae in early developing turbot (Scophthalmus maximus L.) larvae. J App Microbiol 84: 227-233.

16. Gram L, Melchiorsen J, Spanggaard B, Huber I, Nielsen TF (1999) Inhibition of Vibrio anguillarum by Pseudomonas fluorescens $\mathrm{AH} 2$, a possible probiotic treatment of fish. Appl Environ Microbiol 65: 969-973.

17. Gullian M, Thompson F, Rodriguez J (2004) Selection of probiotic bacteria and study of their immunostimulatory effect in Penaeus vannamei. Aquaculture 233: 1-14.

18. Vieira FN, Buglione CC, Mourino JPL, Jatoba A, Martins ML, et al. (2010) Effect of probiotic supplemented diet on marine shrimp survival after challenge with Vibrio harveyi. Arq Bras Med Vet Zootec 62: 631-638.

19. Nayak SK, Mukherjee SC (2011) Screening of gastrointestinal bacteria of Indian major carps for a candidate probiotic species for aquaculture practices. Aquac Res 42: 1034-1041.

20. Rahman S, Khan SN, Naser MN, Karim MM (2011) Safety issues of isolated probiotic natured bacteria from Bangladesh coastal waters for controlling shrimp diseases. J Sci Res 3: 659-668.

21. Lakshmi B, Viswanath B, Sai Gopal DV (2013) Probiotics as antiviral agents in shrimp aquaculture. J Pathog 2013: 424123

22. Moriarty DJW (1996) Microbial biotechnology: a key ingredient for sustainable aquaculture. Infofish Int 4: 29-33.

23. Ghosh S, Sinha A, Sahu C (2007) Isolation of putative probionts from the intestines of Indian major carps. Isr J Aquacult 59: 127-132.

24. Cutting SM (2011) Bacillus probiotics. Food Microbiol 28: 214-220.

25. FakhryS, Sorrentini I, Ricca E, De Felice M, Baccigalupi L (2008)Characterization of spore forming Bacilli isolated from the human gastrointestinal tract. J Appl Microbiol 105: 2178-2186.

26. Hong HA, Khaneja R, Tam NM, Cazzato A, Tan S, et al. (2009) Bacillus subtilis isolated from the human gastrointestinal tract. Res Microbiol 160: 134-143.

27. Hong HA, To E, Fakhry S, Baccigalupi L, Ricca E, et al. (2009) Defining the natural habitat of Bacillus spore-formers. Res Microbiol 160: 375-379.

28. Hoyles L, Honda H, Logan NA, Halket G, La Ragione RM, et al. (2012) Recognition of greater diversity of Bacillus species and related bacteria in human faeces. Res Microbiol 163: 3-13.

29. Ghelardi E, Celandroni F, Salvetti S, Gueye SA, Lupetti A, et al. (2015) Survival and persistence of Bacillus clausii in the human gastrointestinal tract following oral administration as spore-based probiotic formulation. J Appl Microbiol 119: 552-559.

30. Guidoli MG, Santinón JJ, Pasteris SE, Sánchez S, Nader-Macías MEF (2015) Isolation and Selection of Potentially Beneficial Autochthonous Bacteria for Piaractus mesopotamicus Aquaculture Activities. J Bioprocess Biotech 5: 254.

31. Pasteris SE, Babot GR, Otero MC, Bühler MI, Nader-Macías ME (2009) Beneficial properties of lactic acid bacteria isolated from a Rana catesbeiana hatchery. Aquac Res 40: 1605-1615.
32. Pasteris SE, Bühler MI, Nader-Macías ME (2012) Probióticos en acuicultura. In: Probióticos y Salud, first ed. (ed. by Ramos A, Nader-Macías MEF, Monteoliva M) pp: 316-341. Diaz de Santos, Madrid.

33. Brunt J, Austin B (2005) Use of a probiotic to control lactococcosis and streptococcosis in rainbow trout, Oncorhynchus mykiss (Walbaum). J Fish Dis 28: 693-701

34. Bagheri T, Hedayati SA, Yavari V, Alizade M, Farzanfar A (2008) Growth, survival and gut microbial load of Rainbow Trout (Onchorhynchus mykiss) fry given diet supplemented with probiotic during the two months of first feeding. Turk J Fisheries and Aquat Sci 8: 43-48.

35. CONICET (Consejo Nacional de Investigaciones Científicas y Técnicas) UNNE (Universidad Nacional del Nordeste) (2013) Composición para mejora la cría de peces de agua dulce y método de mejoramiento de la cría. Country granting the patent: Argentina. Patent number: 20130103820

36. Torrentera L, Tacon A (1999) La producción de alimento vivo y su importancia en acuacultura. Una diagnosis. FAO-Italia.

37. Da Silva AB, Vinatea JE, Alcantara F (1988) Manual de reproducción de peces Colossoma (pacú y tambaqui). First ed., Tarapoto, San Martín, Perú: FAO's Trust Fund, Proyect GCP/RLA/075/ITA

38. Gómez MI, Sánchez S, Fuentes CM (2014) Shrinkage of Prochilodus lineatus (Valenciennes, 1847) larvae preserved in either ethyl-alcohol or formalin in relation to their developmental stage and feeding condition. J Appl Ichthyol 30: 140-144.

39. Culling CFA (1974) Handbook of histopathological and histochemica techniques: including museum techniques. $3^{\text {rd }}$ edition. Butterworth's \& Co Publishers Ltd. London.

40. Faramarzi M, Kiaalvandi S, Lashkarbolooki M, Iranshahi F (2011) The investigation of Lactobacillus acidophilus as probiotics on growth performance and disease resistance of rainbow trout (Oncorhychus mykiss). Am Euras Sci Res 6: 32-38.

41. Kapareiko D, Lim HJ, Schott EJ, Hanif A, Wikfors GH (2011) Isolation and evaluation of new probiotic bacteria for use in shellfish hatcheries, Effects of a Vibrio sp. probiotic candidate upon survival of oyster larvae (Crassostrea virginica) in pilot-scale trials. J Shellf Res 30: 617-625.

42. Miguel Angel MR, Corredor JC, Romero Hurtado CS (2013) Histological Study of the Digestive System in Different Stages of Development of Pacu (Piaractus brachypomus). Rev Med Vet 25: 21-38.

43. Domitrovic HA (1992) Localización histoquímica de fosfatasa alcalina y ácida en tracto digestivo de Prochilodus platensis (Holmberg 1880). Revista de Ictiología 1: 69-77.

44. Aires E, Dias E, Orsi M (1999) Ultrastructural features of the glandular region of the stomach of Piaractus mesopotamicus (Holmberg, 1887) with emphasis on the oxyntopeptic cell. J Submicrosc Cytol Pathol 31: 287-293.

45. Treviño L, Alvarez-González CA, Perales-García N, Arévalo-Galán L, Uscanga-Martiínez A, et al. (2010) A histological study of the organogenesis of the digestive system in bay snook Petenia splendida Günther (1862), from hatching to the juvenile stage. J Appl Ichthyol 27: 73-82.

46. Standen BT, Rodiles A, Peggs DL, Davies SJ, Santos GA, et al. (2015) Modulation of the intestinal microbiota and morphology of tilapia, Oreochromis niloticus, following the application of a multi-species probiotic. Appl Microbio Biotechnol 99: 8403-8417.

47. Merrifield DL, Bradley G, Harper GM, Baker RTM, Munn CB, et al. (2011) Assessment of the effects of vegetative and lyophilized Pediococcus acidilactici on growth, feed utilization, intestinal colonization and health parameters of rainbow trout (Oncorhynchus mykiss Walbaum). Aquac Nutr 17: 73-79.

48. Rodríguez Estrada U, Satoh S, Haga Y, Fushimi H, Sweetman J (2009) Effects of single and combined supplementation of Enterococcus faecalis, mannan oligosaccharide and polyhydrobutyric acid on growth performance and immune response of rainbow trout (Oncorhynchus mykiss). Aquac Sci 57: 609-617. 